\title{
EFFECT OF THE ELECTROLYSIS REGIME ON THE STRUCTURAL CHARACTERISTICS OF HONEYCOMB-LIKE ELECTRODES
}

\author{
Nebojša D. Nikolić1, Goran Brankovićé, Miomir G. Pavlović ${ }^{1}$ \\ ${ }^{1}$ ICTM-Institute of Electrochemistry, University of Belgrade, Njegoševa 12, Belgrade, Serbia \\ ${ }^{2}$ Institute for Multidisciplinary Research, University of Belgrade, Kneza Višeslava 1a, Belgrade, Serbia \\ nnikolic@tmf.bg.ac.rs
}

\begin{abstract}
The effect of different current regimes of electrolysis on the micro- and nanostructural characteristics of open porous structures was examined by the analysis of honeycomb-like copper electrodes obtained by constant galvanostatic (DC) electrodeposition and by regimes of pulsating (PC) and reversing (RC) current. An increase in the number of holes formed by detached hydrogen bubbles, the decrease in wall width between holes and changes in surface morphology around holes from cauliflower-like agglomerates of copper grains to dendrites were observed in the following order: the DC, PC and RC regime. The hole size formed in the RC regime was smaller than the hole size formed in the DC and PC regimes. Analysis of the obtained structural characteristics showed that the specific surface area of the honeycomb-like electrodes was increased by the application of the $\mathrm{PC}$ and $\mathrm{RC}$ regimes in relation to the $\mathrm{DC}$ regime.
\end{abstract}

Keywords: copper; electrodeposition; morphology; hydrogen bubbles; dendrite

\section{ВЛИЈАНИЕ НА РЕЖИМОТ НА ЕЛЕКТРОЛИЗАТА ВРЗ СТРУКТУРНИТЕ КАРАКТЕРИСТИКИ НА САК̈ЕСТИТЕ ЕЛЕКТРОДИ}

Беше испитувано влијанието на различните режими на струјата при електролизата врз микро- и наноструктурните карактеристики на отворените порозни структури со анализа на саќестите електроди добиени со константна галваностатична (DC) електродепозиција и со режим на пулсирачка (PC), како и повратна (RC) струја. Со зголемувањето на бројот на отвори образувани од одделни водородни меурчиња се намалува дебелината на образуваниот sид и се менува површинската морфологија околу отворите од формата на агломерати на бакарните зрна налик на карфиол, во форма на дендрити, и тоа според следниот ред на промената на режимот на струјата: DC, PC и $\mathrm{RC}$. Анализата на добиените структурни карактеристики покажува дека специфичната надворешна површна на саќестите електроди се зголемува со примена на режимите PC и RC во однос на DC струјата.

Клучни зборови: бакар; електродепозиција; морфологија; водородни меурчња; дендрити.

\section{INTRODUCTION}

Electrochemical deposition processes have been shown to be a very valuable way to obtain open porous structures with an extremely high surface area $[1,2]$. These structures, known as 3D foam or the honeycomb- like foam, are of considerable academic and technological significance for potential application as electrodes in many electrochemical devices, such as fuel cells, batteries and sensors [1], as well as in catalysis [3]. They are formed by electrodeposition processes at high overpotentials and current densities where, 
parallel to metal electrodeposition, a hydrogen evolution reaction occurs. The main characteristics of honeycomb-like structures are holes formed by detached hydrogen bubbles and the agglomerates of metal grains or dendrites that form around them $[1,2,4]$. The specific surface area of this type of electrode is determined by the number and size of holes formed by detached hydrogen bubbles as well as by the wall width between them [5]. In addition to copper [1, 2], which is the most studied system, the formation of open porous structures of other metals, such as nickel [6], silver [7], gold [8] and lead [9], has been also investigated.

The number and size of holes, as well as the wall width between them, depend on the conditions of electrodeposition and the electrolysis regime. The parameters of electrolysis enabling the production of the honeycomb-like electrodes in constant regimes (both galvanostatic and potentiostatic ones) have been well-examined and systematized $[1,2]$. The addition of additives to the electroplating solution $[5,10-12]$ can have a significant effect on the formation of this electrode type. The additives used for the improvement of the micro- and nanostructural characteristics of honeycomb-like electrodes are the same as those used in bright copper electroplating [13, 14]. The effects of these additives on the specific surface area of honeycomb-like electrodes are equivalent to those obtained with the application of periodically changing regimes of electrolysis, such as pulsating overpotential (PO) [15-17], pulsating current (PC) [18-20] and reversing current (RC) [21] regimes.

An increase has been observed in the specific surface area of honeycomb-like electrodes produced by the $\mathrm{RC}$ regime in relation to those produced in the galvanostatic regime (DC mode) at a current density equal to the average current density in the $\mathrm{RC}$ regime [22]. However, for the same cathodic current density and cathodic time, the same average current density is achieved by the regulation of the anodic current density / anodic time ratio. From the point of view of the formation of honeycomb-like electrodes, some combinations of the anodic current density
/ anodic time ratio can produce copper deposits with worse structural characteristics than those obtained in the DC mode [22]. For that reason, it is necessary to propose some new way for the comparison of structural characteristics of honeycomb-like electrodes obtained by different electrolysis regimes. In this study, in a manner based on the same applied current density of electrodeposition (the DC regime), the current density amplitude (the PC regime) and the cathodic current density (the $\mathrm{RC}$ regime) with the same pause to pulse ratio (in the PC and RC regimes) are presented and analyzed.

\section{EXPERIMENTAL}

Copper electrodeposition was performed from $0.15 \mathrm{M} \mathrm{CuSO}_{4}$ in $0.50 \mathrm{M} \mathrm{H}_{2} \mathrm{SO}_{4}$ at room temperature using cylindrical copper wires as the working electrodes. The counter electrode was pure copper. Copper was electrodeposited in the galvanostatic regime and by the regimes of pulsating and reversing current.

Copper was electrodeposited galvanostatically at a current density of $440 \mathrm{~mA} \mathrm{~cm}^{-2}$ (this type of electrolysis is further denoted as the DC regime).

In the $\mathrm{PC}$ regime, the current density amplitude, $j_{\mathrm{A}}$, of $440 \mathrm{~mA} \mathrm{~cm} \mathrm{~cm}^{-2}$, deposition pulse of $10 \mathrm{~ms}$ and pause duration of $10 \mathrm{~ms}$ were selected (this type is further denoted as PC).

In the $\mathrm{RC}$ regime, the cathodic current density, $j_{\mathrm{c}}$, of $440 \mathrm{~mA} \mathrm{~cm}^{-2}$, the anodic current density, $j_{\mathrm{a}}$ of $200 \mathrm{~mA} \mathrm{~cm}^{-2}$, the cathodic pulse duration, $t_{\mathrm{c}}$, and the anodic pulse duration, $t_{\mathrm{a}}$, of $10 \mathrm{~ms}$ were selected (this type is further denoted as RC).

Copper was electrodeposited with quantities of electricity of $10 \mathrm{~mA} \mathrm{~h} \mathrm{~cm}^{-2}$.

The obtained copper deposits were examined using a scanning electron microscope (TESCAN Digital Microscopy).

The average current efficiency of hydrogen evolution, $\eta_{\mathrm{I}, \mathrm{av}}\left(\mathrm{H}_{2}\right)$, was determined using the experimental procedure described in Refs. $[18,19$, 21]. 


\section{RESULTS AND DISCUSSION}

Figure 1 shows the honeycomb-like structures obtained in the constant galvanostatic (DC) regime (Figure 1a), the pulsating current $(\mathrm{PC})$ regime (Figure $1 \mathrm{~b}$ ) and the reversing current $(\mathrm{RC})$ regime (Figure 1c). The quantities of evolved hydrogen spent in the formation of these structures corresponded to the following average current efficiencies of hydrogen evolution, $\eta_{\mathrm{I}, \mathrm{av}}\left(\mathrm{H}_{2}\right): 36.0 \%$ (the DC regime) [19], 30.0\% (the PC regime) [19] and $21.2 \%$ (the RC regime) [22].

Analysis of the honeycomb-like structure electrodeposited at a constant current density of $j=$ $440 \mathrm{~mA} \mathrm{~cm}^{-2}$ (the DC regime; Figure 1a) revealed the presence of two types of holes formed by detached hydrogen bubbles: (a) individual holes (or "non-coalesced" holes; Figure 2a), and (b) holes obtained by the coalescence of closely formed hydrogen bubbles (or "coalesced" holes; Figure 2b). Very disperse cauliflower-like agglomerates of copper grains were formed between holes (Figure 2c) and the presence of deep irregular channels of detached hydrogen bubbles that had formed around the small copper grain agglomerates was easily noted. The number and size of holes and the wall width between them were determined by the quantitative analysis of SEM micrographs, shown in Figures 1a and 2. The overall number of holes formed by detached hydrogen bubbles was estimated to be 170 per $\mathrm{mm}^{2}$ surface area of the copper electrode. The average size of the holes was about $80 \mu \mathrm{m}$, while the wall width between them was $40 \mu \mathrm{m}$.

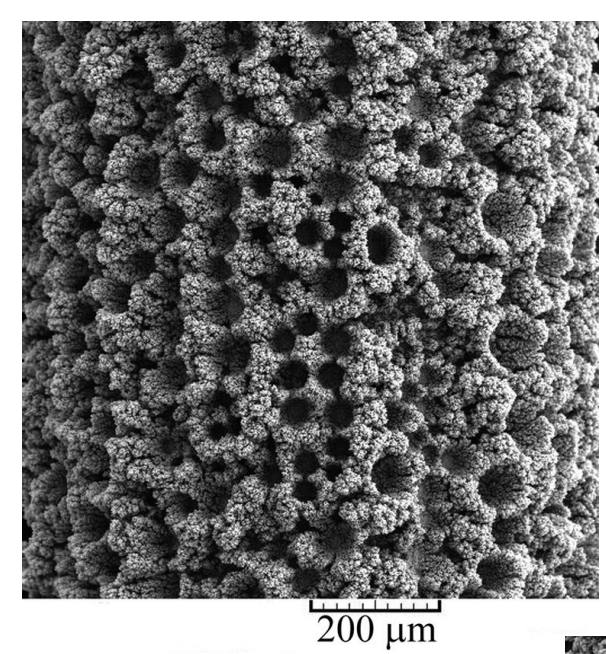

a)
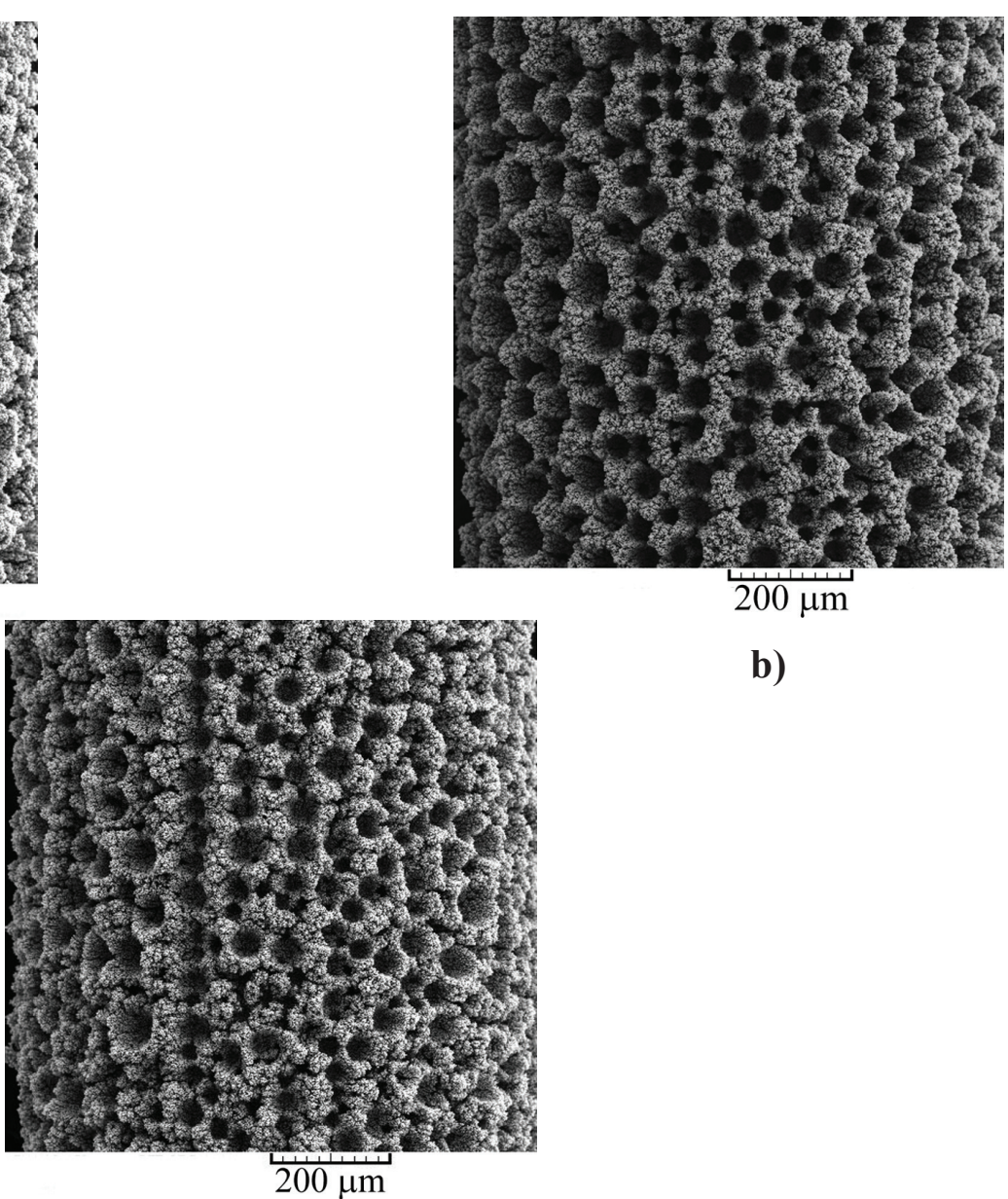

c)

Fig. 1. The honeycomb-like structures obtained: a) in the constant galvanostatic regime (DC), as well as by the regimes of $b$ ) pulsating (PC) and c) reversing (RC) currents 


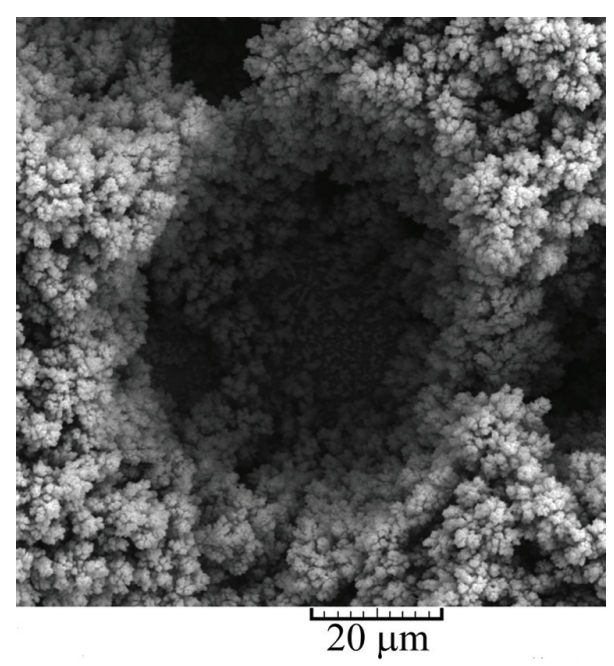

a)

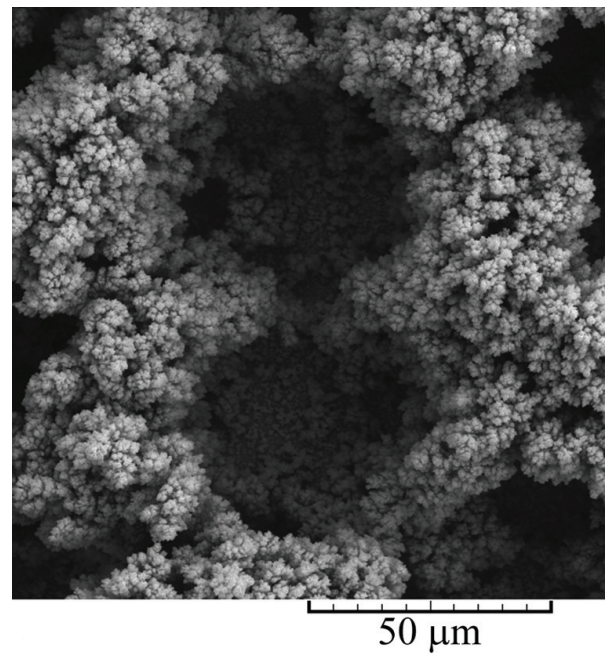

b)

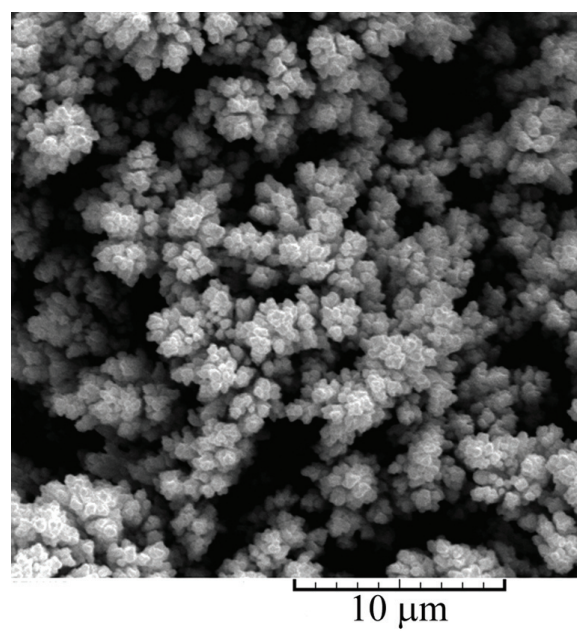

c)

Fig. 2. The typical elements of the honeycomb-like structure obtained by galvanostatic electrodeposition: a) "non-coalesced" hole, b) "coalesced" hole and c) cauliflower-like agglomerates of copper grains formed between holes

The application of the $\mathrm{PC}$ regime with a deposition pulse of $10 \mathrm{~ms}$ and a pause of $10 \mathrm{~ms}$ led to a suppression of coalescence of closely formed hydrogen bubbles (Figure 1b). Due to the suppressed coalescence of closely formed hydrogen bubbles, the number of formed holes was greater than that in the DC regime. The number of holes formed by detached hydrogen bubbles in the PC regime was estimated to be 260 per $\mathrm{mm}^{2}$ surface area of the copper electrode. A typical hole obtained after the detachment of hydrogen bubbles from the electrode surface is shown in Figure 3a, while cauliflower-like agglomerates of copper grains formed between holes, as shown in Figure $3 b$. The average hole size was about $80 \mu \mathrm{m}$ and it was equal to the size of non-coalesced holes obtained in the DC regime. In Figure $3 \mathrm{~b}$ it can be noted that the small copper agglomerates inside large cauliflower-like agglomerates were packed closer to each other in relation to those packed in the DC regime. Due to the denser packing of cauliflower-like copper grain agglomerates, a decrease in the wall width between holes was observed and the estimated wall width in the honeycomb-like structure obtained by the PC regime was $30 \mu \mathrm{m}$. 


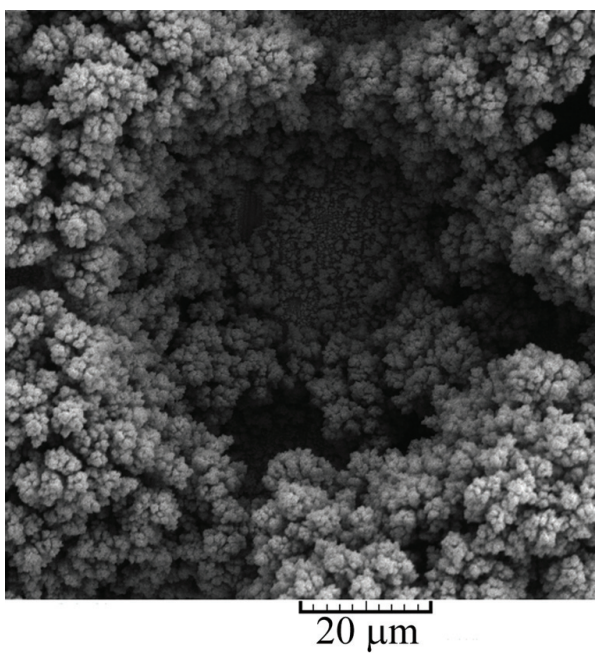

a)

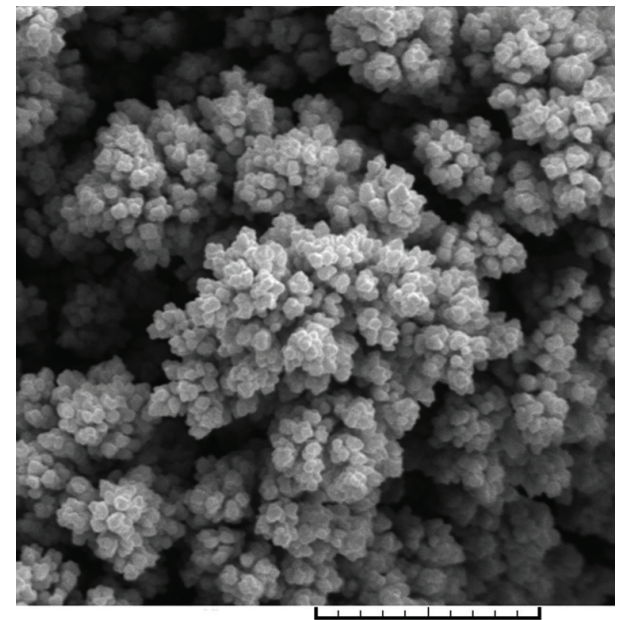

$10 \mu \mathrm{m}$

Fig. 3. The typical elements of the honeycomb-like structure obtained by the pulsating current (PC) regime: a) "non-coalesced" hole and b) cauliflower-like agglomerates of copper grains formed between holes

The analysis of the honeycomb-like structure obtained by the $\mathrm{RC}$ regime with an anodic current density of $200 \mathrm{~mA} \mathrm{~cm}{ }^{-2}$ also showed the absence of holes formed by the coalescence of closely formed hydrogen bubbles. The number of holes formed by detached hydrogen bubbles was estimated to be 280 per $\mathrm{mm}^{2}$ surface area of the copper electrode. The mild increase in the number of formed holes in relation to that obtained in the PC regime can be ascribed to the improvement of the current density distribution at the growing electrode surface [23]. A typical hole obtained by this square-wave RC is shown in Figure $4 \mathrm{a}$, and the average diameter of these holes was about $50 \mu \mathrm{m}$. The morphology of the electrodeposited copper between holes is shown in Figure 4b. It can be noted by the analysis of Figure $4 \mathrm{~b}$ that dendrites had formed at the tops of small agglomerates of copper grains; one dendrite from Figure $4 \mathrm{~b}$ is shown at increased magnification in Figure 4c. From Figure 4b, it can be also noted that the deep irregular channels around small copper agglomerates were almost lost, making this honeycomb-like structure more compact than those obtained in both the DC and $\mathrm{PC}$ regimes. Due to the increased compactness of the honeycomb-like structure, a further decrease in the wall width was observed. The wall width between holes in the honeycomblike structure obtained by the $\mathrm{RC}$ regime was $28 \mu \mathrm{m}$. It can also be seen in Figure 4b that the spherical diffusion layers inside the linear diffusion layer of the macroelectrode were formed around small agglomerates of copper grains. Anyway, it is clear that the application of the RC regime led to a redistribution of evolved hydrogen, decreasing the contribution of generated hydrogen to the creation of channel structure through the interior of the deposit and increasing the compactness of the formed structures (the current density distribution effect) $[17,20]$.

As already mentioned, the quantities of evolved hydrogen and hence the average current efficiencies of hydrogen evolution decreased with the application of periodically changing regimes of electrolysis. The average current efficiency of hydrogen evolution, $\eta_{\mathrm{I}, \mathrm{av}}\left(\mathrm{H}_{2}\right)$ for the honeycomb-like electrode formed by the PC regime, was $16.7 \%$ smaller than $\eta_{\mathrm{I} \text {,av }}\left(\mathrm{H}_{2}\right)$ for that obtained with the DC regime. This difference was greater when the values of $\eta_{\mathrm{I}, \mathrm{av}}\left(\mathrm{H}_{2}\right)$ obtained for the honeycomb-like structures in the DC and $\mathrm{RC}$ regimes were compared. Then, a difference of $41.1 \%$ was obtained. 


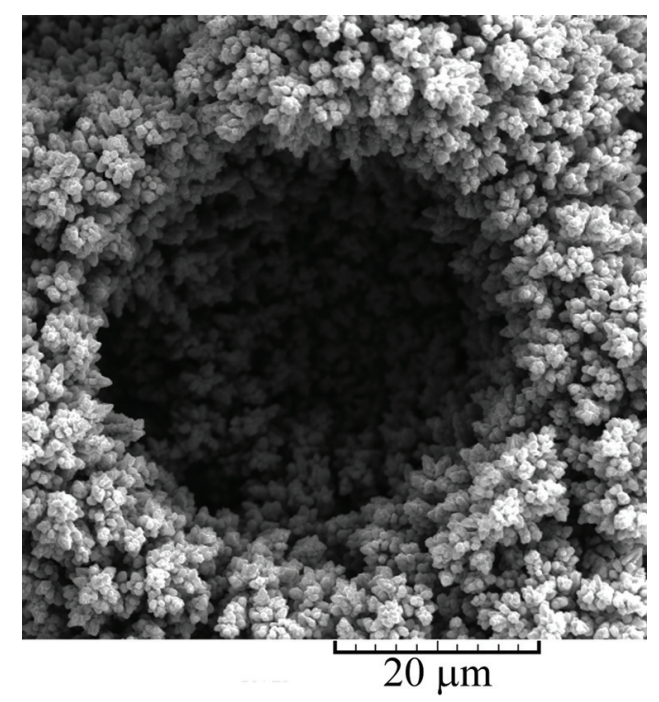

a)

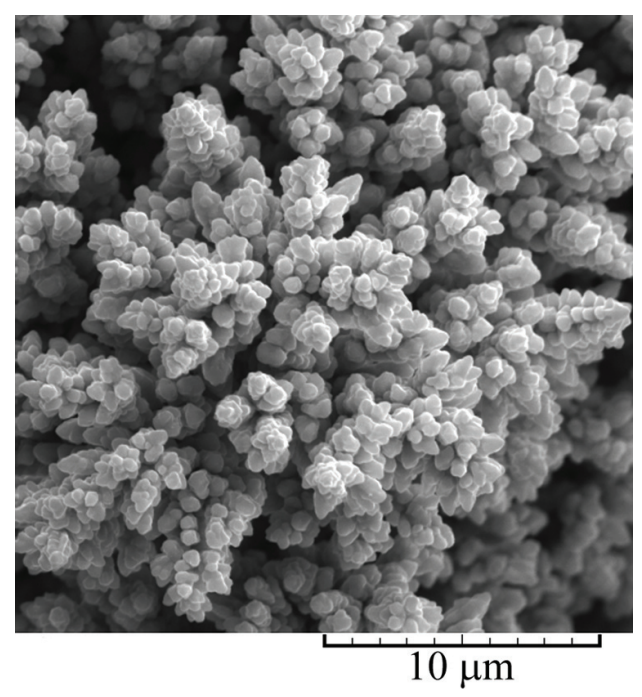

b)

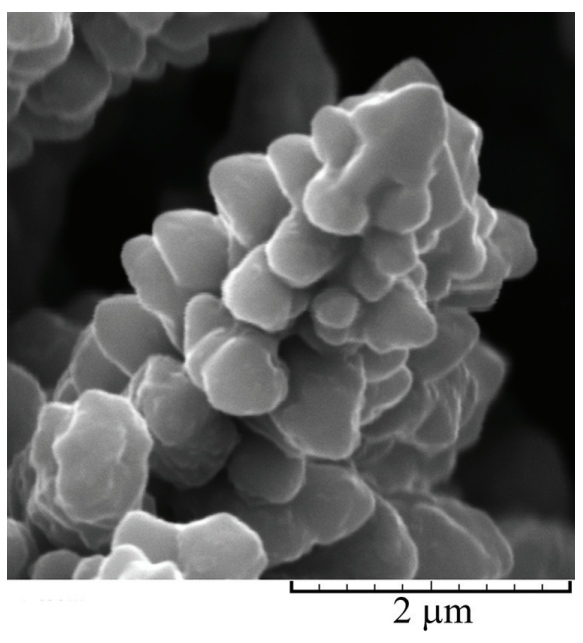

c)

Fig. 4. The typical elements of the honeycomb-like structure obtained by the reversing current (RC) regime: a) "non-coalesced" hole, b) cauliflower-like agglomerates of copper grains formed between holes with small dendrites at their tops and c) a small dendrite formed at the top of an agglomerate of copper grains

Simultaneously, the specific surface area of the honeycomb-like electrodes determined by the number and the size of holes, as well as by the wall width between them was increased by the application of the $\mathrm{PC}$ and $\mathrm{RC}$ regimes. The number of holes formed by detached hydrogen bubbles increased in the following order: the DC regime, the PC regime, and finally, the largest number of holes was formed in the RC regime. In the same order, the wall width between holes decreased. On the other hand, the average size of holes formed by the
$\mathrm{RC}$ regime was smaller than that obtained for both the DC and PC regimes.

The change in the copper surface morphology around holes from very disperse cauliflower-like agglomerates of copper grains to relatively compact ones with dendrites on their tops can be explained since, generally, two types of pores are formed by the hydrogen evolution reaction during the electrodeposition process [24]. The first type are macro pores (or holes) formed by detached hydrogen bubbles. The origin of these pores is the hydrogen 
bubbles that formed in the initial stage of the electrodeposition process. These hydrogen bubbles are responsible for the creation of the honeycomb-like structure and they do not contribute to solution stirring and to changes in hydrodynamic conditions in the near-electrode layer after detachment from the electrode surface. It can be supposed that the same quantity of evolved hydrogen is spent for the creation of macro pores because the current density, the current density amplitude and the cathodic current density were same.

The origin of the second type of pores is hydrogen bubbles generated at the tops of the agglomerates of copper grains during the growth process (the current density distribution effect) [24]. The copper grain agglomerates are formed at the electrode surface in the initial stage of electrodeposition together with hydrogen bubbles. Some of the freshly formed hydrogen bubbles will coalesce with hydrogen bubbles formed in the initial stage of electrodeposition, leading to their growth with electrolysis time (an increase in macro pores). Meanwhile, some of the newly formed hydrogen bubbles will not coalesce with primarily formed hydrogen bubbles because they are situated between freshly formed copper nuclei, which represent a barrier to coalescence with hydrogen bubbles formed in the initial stage of electrodeposition and the development of large hydrogen bubbles is suppressed. These hydrogen bubbles will detach from the electrode surface very quickly, forming micro- and nanopores through the interior of the deposit. A "current of hydrogen" is formed by these small detached hydrogen bubbles, causing solution stirring and a change in the hydrodynamic conditions in the nearelectrode layer. Of course, these micro- and nanopores make the channel structure through the interior of the deposit.

Hence, the morphology of deposit between holes is determined by the difference between the overall quantity of evolved hydrogen and that spent for the formation of macro pores. A decrease in this difference, which causes stirring of the solution in the near-electrode layer, was obtained by the application of the PC and RC regimes, leading to a change in the morphology of electrodeposited copper from very disperse agglomerates of copper grains to those with dendrites on the tops.

The concept of "effective overpotential" is proposed to explain the formation of honeycomb-like structures by different electrolysis regimes. This concept was originally proposed to explain the change in surface morphology during copper electrodeposition in the constant potentiostatic regime at high overpotentials where, parallel to copper electrodeposition, strong hydrogen evolution occurs [2, 4].This concept was also found to be valid for the PC and $\mathrm{RC}$ regimes, denoted as "effective overpotential amplitude" [20, 21]. According to this concept, when hydrogen evolution is vigorous enough, then the electrodeposition process occurs at some overpotential which is effectively lower than the specified one, and this overpotential is denoted by an "effective" deposition process. From the morphological point of view, this means that the morphologies of metal deposits become similar to those obtained at some lower overpotentials where hydrogen evolution does not occur or it is minimal.

The appearance of dendrites clearly indicated that the effectiveness of the solution stirring decreased with electrodeposition at a periodically changing rate. Due to the decrease in the effectiveness of solution stirring in the near-electrode layer, the thickness of the diffusion layer increased and the limiting diffusion current density decreased, causing an increase in the degree of diffusion control of the electrodeposition process. From the point of view of the mechanism of electrodeposition processes in the hydrogen co-deposition range, this means that the effective overpotential amplitude will increase with the application of the PC and RC regimes. The change in the morphology of electrodeposited copper from very disperse agglomerates of copper grains to dendrites (Figures 2c, 3b, 4b and c) clearly 
points to the increase in the overpotential of the electrodeposition process with the application of the PC and RC regimes.

Aside from the increase in the specific surface area of the honeycomb-like electrodes, another convenient aspect of the application of periodically changing electrolysis regimes on the formation of the honeycomb-like structures was found, i.e. an improvement in structural stability. It is a well-known fact that the structural stability of a deposit is closely associated with the quantity of hydrogen evolved at the electrode surface during the electrodeposition process [19, 21, 25]. A smaller quantity of evolved hydrogen and better structural stability of the deposit is obtained. The decrease in the quantity of evolved hydrogen spent for the formation of the honeycomb-like electrodes by the $\mathrm{RC}$ regime clearly indicates an improvement in the structural stability of these electrodes in relation to those obtained by the other electrolysis regimes, such as the PC regime and the constant galvanostatic regime. The main problem with the commercial application of periodically changing regimes of electrolysis in the production of the honeycomb-like electrodes is the high price of a pulse rectifier, which is much greater than the cost of a DC unit [26]. Further developments in the electronic industry will probably decrease the cost of these rectifiers and will enable their broader application in electrochemical technologies.

\section{CONCLUSIONS}

A comparative analysis of the honeycomblike structures obtained by both constant galvanostatic (DC) and periodically changing regimes (pulsating $(\mathrm{PC})$ and reversing $(\mathrm{RC})$ currents) of electrolysis was performed. In all experiments, the applied current density (the DC regime), the current density amplitude (the PC regime) and the cathodic current density (the $\mathrm{RC}$ regime) were the same $\left(440 \mathrm{~mA} \mathrm{~cm}^{-2}\right)$. In the PC and $\mathrm{RC}$ regimes, the selected values of the deposition pulse (and the cathodic pulse duration) and pause duration (and the anodic pulse duration) were $10 \mathrm{~ms}$. In the $\mathrm{RC}$ regime, the anodic current density was $200 \mathrm{~mA} \mathrm{~cm}^{-2}$.

The quantities of evolved hydrogen and hence the average current efficiencies of hydrogen evolution spent for the formation of the honeycomb-like electrodes decreased by the application of the $\mathrm{PC}$ and $\mathrm{RC}$ regimes. The number of holes formed by detached hydrogen bubbles increased and the wall width between holes decreased in the following order: the $\mathrm{DC}, \mathrm{PC}$ and $\mathrm{RC}$ regimes. In the same order, a change in copper surface morphology from very disperse cauliflower-like agglomerates of copper grains to relatively compact ones with dendrites on their tops was observed. The average size of the holes formed in the $\mathrm{RC}$ regime was smaller than that formed in the $\mathrm{DC}$ and $\mathrm{PC}$ regimes.

On the basis of the obtained values for the overall number of formed holes, the hole size and the wall width between holes, the increase in the specific surface area of the honeycomb-like electrodes with the application of a periodically changing electrolysis regime was concluded.

Acknowledgments. The work was supported by the Ministry of Education, Science and Technological Development of the Republic of Serbia under the research project: "Electrochemical synthesis and characterization of nanostructured functional materials for application in new technologies" (No. 172046).

\section{REFERENCES}

[1] H. Shin, J. Dong, M. Liu, Nanoporous structures prepared by an electrochemical deposition process, Adv. Mater., 15, 1610-1614 (2003).

[2] N. D. Nikolić, K. I. Popov, Hydrogen Co-deposition Effects on the Structure of Electrodeposited Copper, in: Modern Aspects of Electrochemistry, Electrodeposition: Theory and Practice, S. S. Djokić (Ed), Vol. 48, Springer, 2010, pp 1-70.

[3] J. Yin, J. Jia, L. Zhu, Macroporous Pt modified glassy carbon electrode: Preparation and electro- 
catalytic activity for methanol oxidation, Int. $J$. Hydrogen Energy, 33, 7444-7447 (2008).

[4] N. D. Nikolić, K. I. Popov, Lj. J. Pavlović, M. G. Pavlović, The effect of hydrogen codeposition on the morphology of copper electrodeposits. I. The concept of effective overpotential, J. Electroanal. Chem., 588, 88-98 (2006).

[5] H. Shin, M. Liu, Copper foam structures with highly porous nanostructured walls, Chem. Mater., 16, 5460-5464 (2004).

[6] C. A. Marozzi, A. C. Chialvo, Development of electrode morphologies of interest in electrocatalysis. Part 1: Electrodeposited porous nickel electrodes, Electrochim. Acta, 45, 2111-2120 (2000).

[7] S. Cherevko, C. Chung, Impact of key deposition parameters on the morphology of silver foams prepared by dynamic hydrogen template deposition, Electrochim. Acta, 55, 6383-6390 (2010).

[8] S. Cherevko, C. Chung, Direct electrodeposition of nanoporous gold with controlled multimodal pore size distribution, Electrochem. Commun., 13, 16-19 (2011).

[9] S. Cherevko, X. Xing, C. Chung, Hydrogen template assisted electrodeposition of sub-micrometer wires composing honeycomb-like porous $\mathrm{Pb}$ films, Appl. Surf. Sci., 257, 8054-8061 (2011).

[10] Y. Li, W Jia, Y. Song, X. H. Xia, Superhydrophobicity of 3D porous copper films prepared using the hydrogen bubble dynamic template, Chem. Mater., 19, 5758-5764 (2007).

[11] J. H. Kim, R. H. Kim, H. Sang Kwon, Preparation of copper foam with 3-dimensionally interconnected spherical pore network by electrodeposition, Electrochem. Commun., 10, 1148-1151 (2008).

[12] K. Tan, M. B. Tian, Q. Cai, Effect of bromide ions and polyethylene glycol on morphological control of electrodeposited copper foam, Thin Solid Films, 518, 5159-5163 (2010).

[13] N. D. Nikolić, Z. Rakočević, K. I. Popov, Structural characteristics of bright copper surfaces, $J$. Electroanal. Chem., 514, 56-66 (2001).

[14] M. G. Pavlović, Lj. J. Pavlović, Morphology and structure of bright electrodeposited metal coatings, Maced. J. Chem. Chem. Eng., 30, 29-43 (2011).

[15] N. D. Nikolić, G. Branković, M. G. Pavlović, K. I. Popov, The effects of the pause to pulse ratio in the regime of pulsating overpotential on the formation of honeycomb-like structures, Electrochem. Commun., 11, 421-424 (2009).
[16] N. D. Nikolić, G. Branković, V. M. Maksimović, M. G. Pavlović, K.I. Popov, Application of pulsating overpotential regime on the formation of copper deposits in the range of hydrogen co-deposition, J. Solid State Electrochem., 14, 331-338 (2010).

[17] N. D. Nikolić, G. Branković, V. M. Maksimović, M.G. Pavlović, K.I. Popov, Influence of potential pulse conditions on the formation of honeycomblike copper electrodes, J. Electroanal. Chem., 635, 111-119 (2009).

[18] N. D. Nikolić, G. Branković, Effect of parameters of square-wave pulsating current on copper electrodeposition in the hydrogen co-deposition range, Electrochem. Commun., 12, 740-744 (2010).

[19] N. D. Nikolić, G. Branković, K. I. Popov, Optimization of electrolytic process of formation of open and porous copper electrodes by the pulsating current (PC) regime, Mater. Chem. Phys., 125, 587-594 (2011).

[20] N. D. Nikolić, G. Branković, V. M. Maksimović, Morphology and internal structure of copper deposits electrodeposited by the pulsating current regime in the hydrogen co-deposition range, J. Solid State Electrochem., 16, 321-328 (2012).

[21] N. D. Nikolić, G. Branković, V. M. Maksimović, Effect of the anodic current density on copper electrodeposition in the hydrogen co-deposition range by the reversing current (RC) regime, $J$. Electroanal. Chem., 661, 309-316 (2011).

[22] N. D. Nikolić, G. Branković, Comparison of open porous copper structures obtained by the different current regimes of electrolysis, Mater. Lett., 70, 11-15 (2012).

[23] K. I. Popov, P. M. Živković, N. D. Nikolić, A mathematical model of the current density distribution in electrochemical cells, J. Serb. Chem. Soc., 76, 805-822 (2011).

[24] N. D. Nikolić, G. Branković, M. G. Pavlović, Correlate between morphology of powder particles obtained by the different regimes of electrolysis and the quantity of evolved hydrogen, Powder Technol., 221, 271-277 (2012).

[25] B. K. Sun, T. J. O` Keefe, Growth of electrolytic copper dendrites and their adhesion to an epoxy resin, Surf. Coat. Technol., 106, 44-52 (1998).

[26] M. S. Chandrasekar, M. Pushpavanam, Pulse and pulse reverse plating - conceptual advantages and applications, Electrochim. Acta, 53, 3313-3322 (2008). 
